\title{
Evaluation of the effects of emotional intelligence status on the communication skills of the faculty of medicine students
}

\author{
Merve KURNAZ AY ${ }^{1}$ (D), Tasnim Musa SUlAIMAN ${ }^{2}$ (D), Nefise GARABLI ${ }^{2}$ (D), Yusuf ACAR ${ }^{2}$ (D), Ihsan UZUNOGLU 2 (D),
} Mehmet AKKUS $^{2}$ (D), Ahmet TOPUZOGLU ${ }^{1}$ (D)

${ }^{1}$ Department of Public Health, School of Medicine, Marmara University, Istanbul, Turkey.

${ }^{2}$ School of Medicine, Marmara University, Istanbul, Turkey.

Corresponding Author: Merve KURNAZ AY

E-mail: mervekurnazmd@gmail.com

Submitted: 20.12.2020 Accepted: 12.03.2021

\begin{abstract}
Objective: In this study, we aimed to evaluate the emotional intelligence levels of the faculty of medicine students and to determine the effects of emotional intelligence levels on communication skills, and the effect of sociodemographic factors on emotional intelligence and communication skills.

Materials and Methods: The faculty of medicine students constituted the sample of this descriptive study. The research was completed with a total of 225 students selected by the haphazard sampling method from each year of a six - year medical school. The data were collected using a questionnaire consisting of sociodemographic characteristics, the Emotional Intelligence Assessment Scale (EIAS), and the Communication Skills Evaluation Scale (CSES).

Results: In our study, 44.4\% ( $\mathrm{n}=100)$ of the participants were male , 55.6\% $(\mathrm{n}=125)$ were female. Approximately, 46.7\% $(\mathrm{n}=105)$ had low, $44.4 \%(100)$ had normal and $8.9 \%(n=20)$ had high emotional intelligence. The communication skills mean score was found to be statistically significantly higher in female than in male. There was a moderate level of a positive correlation between emotional intelligence and communication skills.

Conclusion: In conclusion, participants with a high level of emotional intelligence have better communication skills. In training programs, more emphasis can be given to emotion management, emotional intelligence, and communication skills.

Keywords: Emotional intelligence, Communication, Medicine, Students, Empathy
\end{abstract}

\section{INTRODUCTION}

Emotional intelligence is defined as "the individual's ability to mobilize himself, to continue his path despite setbacks, to control impulses, to postpone satisfaction, to regulate moods, to empathize, to hope and to not allow problems to prevent thinking" [1]. Its adaptive abilities include the ability to evaluate and express emotions, the regulation of emotions and the positive use of emotions for the solution of problems encountered in life. In addition, emotional intelligence includes the ability to accurately perceive, evaluate and express emotions, the ability to create emotions that facilitate the perception of emotions, the ability to effectively use the knowledge acquired with these emotions and the ability to organize emotions for intellectual development and good mood [2]. Generally, it is the ability to be aware of and understand the feelings of others, to understand them correctly and to use the information resulting from these perceptions in a way that will add value to life [3]. Emotions according to Mayer and Salovey; are adaptive organized responses involving physiological, cognitive, motivational and experimental psychological systems, and act as internal events coordinating many psychological sub-systems such as one's physiological responses, cognition, consciousness, and awareness [4]. Emotional intelligence is basically emphasized on two dimensions. These are personal abilities (personal awareness and personal management) and social abilities (social awareness and relationship management). It includes emotional awareness (understanding the impact of emotions in decision making), self-evaluation (knowing and accepting personal weaknesses and advantages) and self-confidence (self-esteem and abilities) within personal awareness. Another important dimension includes important skills such as managing social relations, being effective in conflict management and managing team work [5].

How to cite this article: Ay Kurnaz M, Sulaiman Musa T, Garabli N, et al. Evaluation of the effects of emotional intelligence status on the communication skills of the faculty of medicine students. Marmara Med J 2021; 34(2):157-166. doi: 10.5472/marumj.942621 
In his book Emotional Intelligence, Goleman emphasizes that emotional intelligence is more important than cognitive intelligence, and states that emotional intelligence deprivation can have very bad results in many areas, from family life to professional success and from social relationships to health [6]. In professional life, a person should not only have professional knowledge and skills, but should also know how they can relate to other people and get along with them [7]. In their research on university students, Schutte et al. found that students with high social skills levels had higher levels of emotional intelligence. Also, they displayed more cooperative behaviors and were more successful in close emotional and social relationships [8].

Communication skills can be defined as sensitivity to verbal and non-verbal messages, listening effectively and reacting effectively. In addition to those who think that communication skills are natural and intuitive, in many studies, most elements of communication techniques show that they have learnable and teachable features [9]. According to Omololu, communication skills include; listening, speaking comprehensively, establishing eye contact, promoting speech, praising, using nonverbal behavior appropriately [10]. Effective communication skills can be facilitative in all kinds of human relationships and in all kinds of professional areas [11]. Communication, which forms the basis of interpersonal interaction, has an important place in each individual's life. Professionals' success also depends on their communication skills $[12,13]$.

A certain level of communication skills is required in all professional groups. Communication skills are found to be more important in some professions because the performances of these professions are mostly based on human relations [14]. Communication skills are of great importance in professions where human relations are prominent [15]. In cases where communication is not healthy, people may find themselves alone, excluded or unsuccessful in their professional life. If interpersonal skills are not learned, productivity and satisfaction, which are important for the relationship will be lost [16].

Patient-physician communication is the basis of clinical medicine. Communication is required to cooperate with the patient and ensure his participation in the treatment. There are studies emphasizing the importance of communication at patient care to draw attention to this situation [17]. Physicians' high emotional intelligence and communication skills are important in terms of understanding patients, evaluating their diseases and establishing a patient-physician relationship, which increases treatment compliance $[18,19]$ and patient satisfaction $[20,21]$. In this sense, it is very important that students starting their medical profession, develop their communication skills before stepping into the profession. It is thought that emotional intelligence is the basis of competencies such as patient care, empathy and communication skills in medical education, and skills related to emotional intelligence play a key role in physician-patient and teamwork relationships.[22]. In this context, it is reported that emotional intelligence is predictive in terms of communication skills and interpersonal competence [23]. Therefore,it was aimed to evaluate the emotional intelligence levels of Marmara University School of Medicine students, to determine the effects of emotional intelligence levels on communication skills and to determine the effect of sociodemographic factors on emotional intelligence and communication skills.

\section{MATERIALS and METHODS}

Ethics committee approval and research permit were obtained from the Ethics Committee of Marmara University, School of Medicine (approval number: 09.2020.14). The people who constituted the sample size of the research were asked to participate in the study after being informed about the research and permits. This study was performed in line with the principles of the Declaration of Helsinki. This descriptive study was conducted in January-February 2020. The sample size of the research consisted of 1538 students studying at the Marmara University, School of Medicine in the academic year 2019-2020. The study was completed with a total of 225 students who were willing to participate. Medical education at Marmara Medical School consists of six academic years. The students from each year were selected by haphazard sampling method.

The data were collected with a questionnaire consisting of sociodemographic features filled out by the participants under observation, the Emotional Intelligence Assessment Scale (EIAS) and the Communication Skills Evaluation Scale (CSES). EIAS was developed by Hall in 1999 to measure emotional intelligence [24]. The Turkish validity and reliability study was carried out by Ergin with university students in the same year [25]. The scale consists of five sub-groups. These are; awareness of emotions (6 items), controlling emotions (6 items), selfmotivation (6 items), empathy (6 items) and social skills (6 items). Using a Likert type scale consisting of 30 items, it is scored as 1: I totally disagree, 2: I partially disagree, 3: I disagree very little, 4: I agree very little, 5: I partially agree, 6: I totally agree. There is no reversed statement in the assessment. Scores of sub-groups; the scores of the responses given to the items that constitute the sub-group are calculated by adding up the scores. When each sub-group score and emotional intelligence total score increases, it means the emotional intelligence level increases. Emotional intelligence total score shows the level of emotional intelligence in general, regardless of sub-groups. This value ranges from 0 to 180 . It is the score obtained as a result of the sum of the points obtained from 30 items. Emotional intelligence is categorized as low emotional intelligence if it is 129 and below, and high emotional intelligence when it is 155 and above.

A Communication Skills Evaluation Scale was developed by Korkut in 2016 to understand how individuals evaluate their communication skills [26]. Using a Likert type scale consisting of 25 items, it is scored as 5: Always, 4: Often, 3: Sometimes, 2: Rarely and 1: Never. There is no reversed statement in the assessment. The highest score that can be obtained from the scale is 125 and the lowest score is 25. The scale does not have a cut-off point and the increase in the scale score means that the individual's communication skills is assessed positively. 
Variables examined as descriptive in the research were gender, class, place mostly lived in as a child, perceived income level, educational status of parents and families, family type, upbringing, number of people they lived with, number of siblings, thoughts on empathy, if they were able to express themselves or not, willing to communicate and to think, and whether they could listen effectively.

\section{Statistical Analysis}

Descriptive data in the study were presented with meansstandard deviation values and frequency tables. For the statistical analysis of the data, the Chi-Square test was used to compare the classified data, and the Mann-Whitney $U$ test and Kruskal Wallis variance analysis were used to compare continuous variables that did not fit the normal distribution. The suitability of variables to normal distribution was examined using visual (histogram) and analytical methods (KolmogorovSmirnov / Shapiro-Wilk). Correlation coefficients and statistical significance were calculated with the Spearman test for relationships between variables, at least one of which did not fit the normal distribution or ordinal. In this study, $\mathrm{p}<0.05$ was considered statistically significant.

\section{RESULTS}

Sociodemographic characteristics of the participants are presented in Table I. Fifty-five point 6 percent $(n=125)$ of the participants are male and $44.4 \%(\mathrm{n}=100)$ are female. Participants who were in the 1st, 2nd and 3rd years were classified as preclinical, and those who were in the 4 th, 5th and 6 th years were classified as clinical. Fifty point seven percent $(n=114)$ of the participants were preclinical students and $31.6 \%(n=71)$ thought their income was more than their expenses. Seventyseven point three percent of the participants $(n=174)$ stated that they mostly lived in the metropolis / city when they were children. While the education level of the father of $64.4 \%$ ( $n=$ 145) of the participants was university and above, the education level of $45.8 \%(n=103)$ of the mother of the participants was university and above. Ninety point seven percent $(n=204)$ of the participants reported that they had a nuclear family structure and $26.2 \%(n=59)$ reported that they lived alone.

In Table II, $61.3 \%(n=138)$ of the participants defined their child rearing style as supportive, $12 \%(\mathrm{n}=27)$ as overprotective and $6.7 \%(\mathrm{n}=15)$ as oppressive.

Four percent $(n=9)$ of the participants in the research did not think that they were unable to empathize, $14.2 \%(\mathrm{n}=32)$ could not listen effectively, 25.3\% $(n=57)$ had difficulties in interpersonal communication, $17.3 \%(n=39)$ reported that they could not express themselves and 30.7\% $(n=69)$ reported that they were not willing to communicate (Table III).
Table I. Sociodemographic characteristics of the participants

\begin{tabular}{|c|c|c|c|}
\hline & Number(s) & Percentage(\%) \\
\hline \multirow{2}{*}{ Gender } & Female & 125 & 55.6 \\
\hline & Male & 100 & 44.4 \\
\hline \multirow{2}{*}{ Class } & Preclinic & 114 & 50.7 \\
\hline & Clinic & 111 & 49.3 \\
\hline \multirow{3}{*}{$\begin{array}{l}\text { Perceived } \\
\text { income level }\end{array}$} & $\begin{array}{l}\text { Expense more than } \\
\text { income }\end{array}$ & 71 & 31.6 \\
\hline & Expense equal to income & 140 & 62.2 \\
\hline & Expense less than income & 14 & 6.2 \\
\hline \multirow{2}{*}{$\begin{array}{l}\text { Place } \\
\text { mostly lived } \\
\text { as a child }\end{array}$} & Metropolitan / City & 174 & 77.3 \\
\hline & District / Village & 51 & 22.7 \\
\hline \multirow{5}{*}{$\begin{array}{l}\text { Mother's } \\
\text { education } \\
\text { level }\end{array}$} & $\begin{array}{l}\text { No education / has not } \\
\text { finished primary school }\end{array}$ & 11 & 4.8 \\
\hline & Primary school & 31 & 13.8 \\
\hline & Middle school & 17 & 7.6 \\
\hline & High school & 63 & 28.0 \\
\hline & University and above & 103 & 45.8 \\
\hline \multirow{5}{*}{$\begin{array}{l}\text { Father's } \\
\text { education } \\
\text { level }\end{array}$} & $\begin{array}{l}\text { No education / has not } \\
\text { finished primary school }\end{array}$ & 5 & 2.3 \\
\hline & Primary school & 16 & 7.1 \\
\hline & Middle school & 14 & 6.2 \\
\hline & High school & 45 & 20 \\
\hline & University and above & 145 & 64.4 \\
\hline \multirow{3}{*}{$\begin{array}{l}\text { Living } \\
\text { alone or } \\
\text { with other } \\
\text { people }\end{array}$} & With family & 78 & 34.7 \\
\hline & With roommate & 88 & 39.1 \\
\hline & Alone & 59 & 26.2 \\
\hline \multirow{2}{*}{ Family type } & Nuclear family & 204 & 90.7 \\
\hline & Extended family & 21 & 9.3 \\
\hline
\end{tabular}

Table II. Parent child rearing style through the eyes of the participants

\begin{tabular}{|l|l|c|c|}
\hline \multicolumn{1}{|c|}{} & Number(s) & Percentage(\%) \\
\hline \multirow{4}{*}{$\begin{array}{l}\text { Child rearing } \\
\text { style }\end{array}$} & Indifferent & 3 & 1.3 \\
\cline { 2 - 4 } & Inconsistent & 7 & 3.1 \\
\cline { 2 - 4 } & Excessively free & 7 & 3.1 \\
\cline { 2 - 4 } & $\begin{array}{l}\text { Not aware of their } \\
\text { feelings }\end{array}$ & 11 & 4.9 \\
\cline { 2 - 4 } & Oppressive & 15 & 6.7 \\
\cline { 2 - 4 } & Democratic & 17 & 7.6 \\
\cline { 2 - 4 } & Overprotective & 27 & 12.0 \\
\cline { 2 - 4 } & Supportive & 138 & 61.3 \\
\hline & Total & 225 & 100.0 \\
\hline
\end{tabular}


Table III. Participants' opinions about the following items

\begin{tabular}{|l|l|c|c|}
\hline \multicolumn{2}{|c|}{} & Number(s) & Percentage(\%) \\
\hline \multirow{2}{*}{ To establish empathy } & Yes & 216 & 96.0 \\
\cline { 2 - 4 } & No & 9 & 4.0 \\
\hline \multirow{2}{*}{$\begin{array}{l}\text { Difficulty in interpersonal } \\
\text { relationship }\end{array}$} & Yes & 57 & 25.3 \\
\cline { 2 - 4 } Being able to express yourself & No & 168 & 74.7 \\
\cline { 2 - 4 } & Yes & 186 & 82.7 \\
\hline \multirow{2}{*}{ Being willing to communicate } & No & 39 & 17.3 \\
\cline { 2 - 4 } & No & 156 & 69.3 \\
\hline \multirow{2}{*}{ Listening effectively } & Yes & 193 & 30.7 \\
\cline { 2 - 4 } & No & 32 & 85.8 \\
\hline & Total & 225 & 14.2 \\
\hline & & & 100.0 \\
\hline
\end{tabular}

In Table IV, when the averages of the CSES and EIAS scores of the participants were compared according to their sociodemographic characteristics; the average communication skill scores of the females $(102.90 \pm 9.64)$ were found to be statistically significantly higher than in the males $(97.92 \pm 11.65)$ $(\mathrm{p}=0.001)$. When the participants were compared in terms of class, perceived income level, place where they lived mostly as a child, mother education level, father education level, living alone or together and family type, there was no statistically significant difference ( $\mathrm{p}>0.05)$. When the EIAS scores were compared according to their sociodemographic characteristics, the mean scores of the emotional intelligence scale scores of the students in the clinic $(133.35 \pm 19.44)$ were found to be statistically significantly higher than the preclinical students (128.96 \pm 17.17) $(\mathrm{p}=0.026)$. When the participants were compared in terms of gender, perceived income level, place where they mostly lived as a child, mother's education level, father's education level, living alone or together, and family type with EIAS scores, no statistically significant difference was observed ( $p>0.05)$. While there was no statistically significant correlation between age and CSES score ( $p>0.005)$, there was a noteworthy weak (Spearman rho $=0.170)$ significant correlation with EIAS score $(p=0.011)$. When the emotional intelligence sub-groups were examined according to the sociodemographic characteristics of the participants, it was found that in the sub-dimensions of an awareness of emotion and being able to empathize sub-groups, the females scored significantly higher than the males, in the subdimensions of controlling the feelings and self-motivation subgroups, the males scored significantly higher than the females (respectively; $\mathrm{p}=0.040, \mathrm{p}=0.002, \mathrm{p}=0.070, \mathrm{p}=0.077$ ). It was determined that the students in the clinic received higher scores in the empathy and social skills sub-groups than the students in the preclinic (respectively; $\mathrm{p}=0.006, \mathrm{p}=0.010$ ). There was no statistically significant difference between the perceived income level of the participants, the place where they lived as a child, the level of mother education, the level of father education, living alone or together, the number of siblings and family type and emotional intelligence sub-groups $(p>0.05)$. There was a significant positive correlation between age and emotional intelligence sub-groups, self-motivation, empathy and social skills scale scores (respectively; Spearman rho $=0.147$, rho $=$ 0.178 , rho $=0.213)(\mathrm{p}=0.027, \mathrm{p}=0.007, \mathrm{p}=0.001)$.

Table IV. Communication skill scores and emotional intelligence scores according to the sociodemographic characteristics of the participants

\begin{tabular}{|c|c|c|c|c|c|c|c|}
\hline & \multicolumn{2}{|c|}{$\begin{array}{l}\text { Communication } \\
\text { skills Score }\end{array}$} & \multirow[b]{2}{*}{ p } & \multicolumn{2}{|c|}{$\begin{array}{l}\text { Emotional } \\
\text { Intelligence Score }\end{array}$} & \multirow[b]{2}{*}{ p } \\
\hline & & Mean & $\begin{array}{l}\text { Standard } \\
\text { deviation }\end{array}$ & & Mean & $\begin{array}{l}\text { Standard } \\
\text { deviation }\end{array}$ & \\
\hline \multirow[t]{2}{*}{ Gender } & Female & 102.90 & 9.64 & \multirow{2}{*}{0.001} & 130.58 & 19.14 & \multirow{2}{*}{0.559} \\
\hline & Male & 97.92 & 11.65 & & 131.81 & 17.53 & \\
\hline \multirow[t]{2}{*}{ Class } & Pre-clinic & 100.38 & 10.13 & \multirow{2}{*}{0.442} & 128.96 & 17.17 & \multirow{2}{*}{0.026} \\
\hline & Clinic & 101.00 & 11.57 & & 133.35 & 19.44 & \\
\hline \multirow[t]{3}{*}{$\begin{array}{l}\text { Perceived } \\
\text { income } \\
\text { level }\end{array}$} & $\begin{array}{l}\text { Expense } \\
\text { more than } \\
\text { income }\end{array}$ & 101.32 & 10.30 & \multirow{3}{*}{0.883} & 130.42 & 13.70 & \multirow{3}{*}{0.654} \\
\hline & \begin{tabular}{|l|} 
Expense \\
equal to \\
income
\end{tabular} & 100.40 & 11.29 & & 130.45 & 18.64 & \\
\hline & $\begin{array}{l}\text { Expense less } \\
\text { than income }\end{array}$ & 100.35 & 9.39 & & 132.60 & 18.90 & \\
\hline \multirow{2}{*}{$\begin{array}{l}\text { Place } \\
\text { mostly } \\
\text { lived in as } \\
\text { a child } \\
\end{array}$} & $\begin{array}{l}\text { Metropolitan } \\
\text { / city }\end{array}$ & 101.08 & 10.79 & \multirow{2}{*}{0.431} & 130.85 & 18.42 & \multirow{2}{*}{0.671} \\
\hline & $\begin{array}{l}\begin{array}{l}\text { District// } \\
\text { village }\end{array} \\
\end{array}$ & 99.33 & 11.03 & & 132.07 & 18.55 & \\
\hline \multirow[t]{5}{*}{$\begin{array}{l}\text { Mother's } \\
\text { education } \\
\text { level }\end{array}$} & $\begin{array}{l}\text { No education } \\
\text { / has not } \\
\text { finished } \\
\text { primary } \\
\text { school }\end{array}$ & 101.09 & 8.89 & \multirow{5}{*}{0.691} & 133.00 & 17.96 & \multirow{5}{*}{0.507} \\
\hline & \begin{tabular}{|l|}
$\begin{array}{l}\text { Primary } \\
\text { school }\end{array}$ \\
\end{tabular} & 98.87 & 10.27 & & 130.00 & 16.73 & \\
\hline & \begin{tabular}{|l|} 
Middle \\
school
\end{tabular} & 97.58 & 16.14 & & 133.88 & 22.86 & \\
\hline & High school & 101.39 & 10.49 & & 128.60 & 18.21 & \\
\hline & $\begin{array}{l}\text { University } \\
\text { and above }\end{array}$ & 101.27 & 10.41 & & 132.35 & 18.43 & \\
\hline \multirow[t]{5}{*}{$\begin{array}{l}\text { Father's } \\
\text { education } \\
\text { level }\end{array}$} & $\begin{array}{l}\text { No education } \\
\text { / has not } \\
\text { finished } \\
\text { primary } \\
\text { school } \\
\end{array}$ & 101.60 & 4.33 & \multirow{5}{*}{0.768} & 140.20 & 8.34 & \multirow{5}{*}{0.223} \\
\hline & \begin{tabular}{|l|}
$\begin{array}{l}\text { Primary } \\
\text { school }\end{array}$ \\
\end{tabular} & 103.62 & 8.76 & & 135.87 & 16.19 & \\
\hline & \begin{tabular}{|l}
$\begin{array}{l}\text { Middle } \\
\text { school }\end{array}$ \\
\end{tabular} & 98.85 & 16.33 & & 132.07 & 21.40 & \\
\hline & High school & 99.80 & 9.79 & & 125.42 & 21.31 & \\
\hline & $\begin{array}{l}\text { University } \\
\text { and above }\end{array}$ & 100.78 & 10.93 & & 131.97 & 17.37 & \\
\hline \multirow{3}{*}{$\begin{array}{l}\text { Living } \\
\text { alone or } \\
\text { with other } \\
\text { people }\end{array}$} & With family & 100.91 & 9.77 & \multirow{3}{*}{0.295} & 130.50 & 17.10 & \multirow{3}{*}{0.501} \\
\hline & $\begin{array}{l}\text { With } \\
\text { roommate }\end{array}$ & 99.56 & 11.93 & & 130.59 & 19.08 & \\
\hline & Alone & 102.06 & 10.50 & & 132.76 & 19.27 & \\
\hline \multirow[t]{2}{*}{$\begin{array}{l}\text { Family } \\
\text { type }\end{array}$} & $\begin{array}{l}\text { Nuclear } \\
\text { family }\end{array}$ & 100.96 & 10.85 & \multirow{2}{*}{0.300} & 131.07 & 18.14 & \multirow{2}{*}{0.955} \\
\hline & $\begin{array}{l}\text { Extended } \\
\text { family }\end{array}$ & 98.04 & 10.70 & & 131.66 & 21.38 & \\
\hline
\end{tabular}

Communication Skills Evaluation Scale scores and EIA scores are given in Table $\mathrm{V}$ according to the opinions of the participants about themselves. When examined in terms of communication skills; comparing those who did not think that they had difficulty in communicating (102.42 \pm 10.42$)$ with those who thought that they had difficulty (95.57 \pm 
10.53), those who did not think they had difficulty expressing themselves $(101.90 \pm 10.66)$ compared to those who thought they had difficulties $(94.89 \pm 9.89)$, those who were willing to communicate $(102.65 \pm 10.37)$ compared to those who were not willing to communicate $(96.24 \pm 10.65)$ and communication skill scores of those who thought they could listen effectively $(101.39 \pm 10.56)$ were found to be statistically significantly higher than those who did not think they listened effectively $(96.40 \pm 11.73)(\mathrm{p}<0.05)$. However, there was no significant statistical difference in terms of CSES scores between those who thought they could empathize $(100.91 \pm 10.77)$ and those who thought they could not empathize $(95.33 \pm 12.00)(\mathrm{p}>0.05)$.

When the participants were examined in terms of emotional intelligence; comparing those who thought that had no difficulty in communicating amongst people $(133.97 \pm 17.28)$ with those who thought that they had difficulty $(122.75 \pm 19.23)$, those who did not think they had difficulty expressing themselves (133.10 \pm 17.42 ) compared with those who thought they had difficulty $(121.69 \pm 20.29)$, those who were willing to communicate (134.27 $\pm 17.35)$ compared with those who were not willing (124.01 \pm 18.90) and the scores of those who thought they could listen effectively (132.24 \pm 18.20$)$ compared with those who did not think they could listen effectively $(124.37 \pm 18.52)$ were found to be statistically significant ( $\mathrm{p}<0.05)$. However, no statistically significant difference was found in terms of communication skills scores between those who thought they could empathize $(131.19 \pm 18.43)$ and those who thought they could not (129.55 $\pm 19.09)(\mathrm{p}>0.05)$.

Table V. Communication skill scores and emotional intelligence scores according to the participants' opinions

\begin{tabular}{|c|c|c|c|c|c|c|c|}
\hline & \multicolumn{2}{|c|}{$\begin{array}{l}\text { Communication } \\
\text { skills Score }\end{array}$} & \multirow[b]{2}{*}{ p } & \multicolumn{2}{|c|}{$\begin{array}{c}\text { Emotional } \\
\text { Intelligence Score }\end{array}$} & \multirow[b]{2}{*}{ p } \\
\hline & & Mean & \begin{tabular}{|l} 
Standard \\
deviation
\end{tabular} & & Mean & $\begin{array}{l}\text { Standard } \\
\text { deviation }\end{array}$ & \\
\hline \multirow{2}{*}{$\begin{array}{l}\text { To establish } \\
\text { empathy }\end{array}$} & Yes & 100.91 & 10.77 & \multirow{2}{*}{0.195} & 131.19 & 18.43 & \multirow{2}{*}{0.788} \\
\hline & No & 95.33 & 12.00 & & 129.55 & $\mid 19.09$ & \\
\hline \multirow{2}{*}{$\begin{array}{l}\text { Difficulty in } \\
\text { interpersonal } \\
\text { relationship }\end{array}$} & Yes & 95.57 & 10.53 & \multirow{2}{*}{$<0.001$} & 122.75 & $\mid 19.23$ & \multirow{2}{*}{$<0.001$} \\
\hline & No & 102.42 & 10.42 & & 133.97 & 17.28 & \\
\hline \multirow{2}{*}{$\begin{array}{l}\text { Being able } \\
\text { to express } \\
\text { yourself }\end{array}$} & Yes & 101.90 & 10.66 & \multirow{2}{*}{$<0.001$} & 133.10 & 17.42 & \multirow{2}{*}{0.001} \\
\hline & No & 94.89 & 9.89 & & 121.69 & 20.29 & \\
\hline \multirow{2}{*}{$\begin{array}{l}\text { Being } \\
\text { willing to } \\
\text { communicate }\end{array}$} & Yes & 102.65 & 10.37 & \multirow{2}{*}{$<0.001$} & 134.27 & 17.35 & \multirow{2}{*}{$<0.001$} \\
\hline & No & 96.24 & 10.65 & & 124.01 & 18.90 & \\
\hline \multirow{2}{*}{$\begin{array}{l}\text { Listening } \\
\text { effectively }\end{array}$} & Yes & 101.39 & 10.56 & \multirow{2}{*}{0.027} & 132.24 & 18.20 & \multirow{2}{*}{0.030} \\
\hline & No & 96.40 & 11.73 & & 124.37 & 18.52 & \\
\hline
\end{tabular}

When the sub-scales of emotional intelligence were examined according to the opinions of the participants about themselves; participants who stated that they were willing to communicate were found to have significant higher scores in the sub-groups of being aware of their emotions, controlling their emotions, self-motivation and social skills than those who stated that they were not willing to communicate ( $\mathrm{p}=0.004, \mathrm{p}=0.001, \mathrm{p}=0.005, \mathrm{p}=0.002)$. It was found that those who did not think that they had difficulty in expressing themselves had a significantly higher score in the subscales of awareness of their feelings, controlling their feelings, selfmotivation and social skills (respectively; $\mathrm{p}=0.030, \mathrm{p}<0.001, \mathrm{p}=$ $0.002, \mathrm{p}=0.084)$. When comparing those who thought that they could listen actively with those who did not think they could, a higher statistical significance was found in terms of empathy and social skills sub-groups (respectively; $\mathrm{p}=0.007, \mathrm{p}<0.037$ ). It was found that when comparing those who thought that they did not have difficulty in communicating with those who thought they did, a higher statistical significance was found in terms of the subgroups of being aware of their emotions, controlling their emotions, self-motivation and social skills (respectively; $\mathrm{p}=0.047, \mathrm{p}<0.001, \mathrm{p}$ $<0.001, \mathrm{p}=0.005)$. There was no statistically significant difference between the participants who thought they could empathize and those who thought they could not ( $\mathrm{p}>0.05)$.

When the communication skill scores of the participants according to the emotional intelligence sub-groups were examined, it was concluded that as the score obtained from the scale increases in all sub-groups, the communication skill score increases, and those in the high score category for all sub-groups receive a statistically significantly higher communication skill score than those in the low score category $(\mathrm{p}<0.001)$ (Table VI).

Table VI. Communication skill scores of the participants according to emotional intelligence sub-groups

\begin{tabular}{|c|c|c|c|c|c|c|c|}
\hline & \multicolumn{2}{|c|}{ LOW } & \multicolumn{2}{|c|}{ MODERATE } & \multicolumn{2}{|c|}{ HIGH } & \multirow[b]{2}{*}{ p } \\
\hline & Mean & $\begin{array}{l}\text { Standard } \\
\text { deviation }\end{array}$ & Mean & $\begin{array}{l}\text { Standard } \\
\text { deviation }\end{array}$ & Mean & $\begin{array}{l}\text { Standard } \\
\text { deviation } \\
\end{array}$ & \\
\hline $\begin{array}{l}\text { Awareness } \\
\text { of emotions }\end{array}$ & 93.96 & 10.87 & 101.39 & 9.54 & 105.13 & 10.49 & $<0.001$ \\
\hline $\begin{array}{l}\text { Controlling } \\
\text { their } \\
\text { feelings }\end{array}$ & 98.13 & 10.74 & 104.87 & 7.79 & 105.33 & 14.91 & $<0.001$ \\
\hline $\begin{array}{l}\text { Self- } \\
\text { motivation }\end{array}$ & 96.98 & 10.95 & 103.08 & 8.17 & 107.02 & 11.59 & $<0.001$ \\
\hline $\begin{array}{l}\text { Being } \\
\text { able to } \\
\text { empathize }\end{array}$ & 95.40 & 10.19 & 100.94 & 8.77 & 108.23 & 10.19 & $<0.001$ \\
\hline Social skill & 93.83 & 10.36 & 103.31 & 8.00 & 107.18 & 9.87 & $<0.001$ \\
\hline $\begin{array}{l}\text { General } \\
\text { emotional } \\
\text { intelligence }\end{array}$ & 95.60 & 10.28 & 103.75 & 8.05 & 112.10 & 11.89 & $<0.001$ \\
\hline
\end{tabular}

In our study, no statistically significant difference was found when comparing the number of siblings and their parenting style with communication skill score, general emotional intelligence scores and emotional intelligence subscale scores ( $\mathrm{p}>0.05)$.

According to the analysis results of the research data, there was a moderately positive correlation (Spearman rho $=0.534)$ between the CSES scores and the EIES scores $(\mathrm{p}<0.001)$. In addition, when the sub-groups of emotional intelligence; awareness of emotions, controlling emotions, self-motivation, empathy and social skills scores were compared with the CSES scores, a positive statistically 
significant (respectively; Spearman rho $=0.361,0.296,0.399$, $0.476,0.544)$ correlation was detected $(\mathrm{p}<0.001)$.

\section{DISCUSSION}

In our study, it was found that the average communication skill scores of the females were statistically significantly higher than those of the males. Similarly, in a study by Durukan et al. conducted on 140 Turkish teachers based on their communication skills in 2010, it was found that there was a significant difference between gender and communication skills scores but it was in favor of the female teachers [27]. In a study done by Tepeköylü et al. among students of physical education and sports school in 2009, a statistically significant difference was found between gender and communication score, and the communication skills scale score of the female students was found to be significantly higher [28]. Unlike these results, in two studies conducted by Dilekman et al. in 2008 and Kutlu et al. in 2007 on the students of the faculty of education, the communication skills of the education faculty students were examined and there was no significant difference between the communication skills of the students and gender [14,29].

In this study, no significant difference was found between emotional intelligence level and gender. Similar to our study, in the study of Yeniceri et al. conducted with medical faculty students in 2015, no significant difference was found between emotional intelligence level and gender [30]. When examining the studies investigating the relationship between emotional intelligence and gender, different results were found. In a study on university students in Iran, it was shown that there was no difference between emotional intelligence and communication skills in terms of gender [31]. While it was reported that there was no relationship between emotional intelligence scores and gender in the studies conducted by Shuttle et al. in 2001, Kutlu et al. in 2007 and Füsun's in 2002 [8, 32, 33], in many other studies, emotional intelligence scores were found to be higher in females. For example, in a study by Austin et al. conducted on first year medical students, emotional intelligence levels of females were found to be significantly higher compared to males [20]. Similarly, another study by Aslan et al. on health workers, it was found that females had higher levels of emotional intelligence than males [34]. Additionally, in a study conducted on students studying dentistry, it was determined that females' emotional intelligence levels were higher than males' [35].

In a study examining the relationship between interpersonal relationships and emotional intelligence by Schutte et al., social skills, communication and cooperation increased as emotional intelligence scores increased; it was reported that there was no relationship between empathy and awareness of emotions with emotional intelligence scores [8]. In our study, those who thought that they had no difficulty in communicating with people and in expressing themselves, those who were willing to communicate, and those who thought they could listen effectively got significantly higher score than the others from the EIAS.

Effective communication is being able to express, explain and understand oneself. One of the biggest obstacles in effective communication is not being able to explain and express oneself [36]. In this study, the participants who thought that they could express themselves were expected to have higher emotional intelligence and communication skills scores, thus it was concluded that there was a positive relationship in this direction. The communication skill scores of those who did not think they had difficulty in expressing themselves $(101.90 \pm 10.66)$ and those who thought that they did $(94.89 \pm 9.89)$ were found to be statistically significantly higher.

Effective communication depends on listening skills. Therefore, the language skill that human beings learn first is the basis of communication [37]. In this study, it was thought that those who thought they could listen effectively would have higher communication skills scores and this expectation was confirmed. Also, the communication skill scores of those who thought they could listen effectively were found to be statistically significantly higher than those who did not think they could.

In our study, a moderately positive correlation was found between CSES scores and EIES scores. In addition, a statistically significant positive correlation was found between the emotional intelligence sub-groups; awareness of emotions, controlling emotions, self-motivation, empathy and social skills scores and CSES scores. Participants with high emotional intelligence were found to have better communication skills. Similarly, in a study conducted by Kuzu in 2010 with nursing students, it was determined that as the emotional intelligence score averages of the students participating in the study increased, the communication skills mean scores increased, and all emotional intelligence sub-dimensions had a strong positive relationship with each other [38]. In a study conducted by Çetinkaya et al. in 2011 on university students to evaluate the communication skills and emotional intelligence, it was found that there was a positive correlation between the sub-groups of emotional intelligence and the sub-groups of communication skill [7]. In a different study conducted in 2011 by Erginsoy on university students in different departments, the relationship between emotional intelligence and communication skills scale scores was observed and it was reported that a positive relationship between emotional intelligence and communication skills scale sub-groups was found [39]. Accordingly, as emotional intelligence scores increase, communication skills scores also increase. In a study by Schutte et al., as emotional intelligence scores increased, social skills, communication and collaboration also increased. It was reported that there was no relationship between empathy and awareness of emotions with emotional intelligence scores [8].

In a study by Mayer, he found that students in the age group of 18 21 received higher scores in terms of emotional intelligence than students in the age group of 13-16 and he stated that emotional intelligence increases with age at least until the beginning of the young adult years [4]. Also, in a study conducted by Ergin et al., on high school adolescents in 1999, 15-year-olds were found to have lower emotional intelligence than 16 and 17-year-old students, thus concluded that emotional intelligence increases with age [25]. In the study by Harrod and Scheer in 2005 in terms of age and emotional intelligence, it was observed that 
emotional intelligence can develop at any age, and emotional intelligence increases as the age gets older [40]. Furthermore, other studies on this issue also show that emotional intelligence increases with age $[41,42]$. In accordance with the literature, in our study, when the general emotional intelligence level and emotional intelligence sub-groups were examined, it was found that the level of emotional intelligence increased as the age increased. However, in a study conducted with medical faculty students in Mugla, Turkey in 2015, no significant difference was found between age and emotional intelligence and sub-scales of emotional intelligence [30].

In our study, the mean score of emotional intelligence scale scores of the students in the clinic were found to be statistically significantly higher than the preclinical students. On the other hand, in the studies of Yeniceri et al. conducted with medical students, no significant difference was found between class and emotional intelligence [30]. In our study, there was no significant relationship in terms of communication skills between the clinical and preclinical students. Similarly, in the studies of Erigüç and Eriş in 2013 and Dilekman et al. in 2008, there was no significant difference between the communication skills levels of the students according to their class levels [14, 43]. However, unlike the results of the aforementioned studies, in a study conducted in 2002 on nursing students' communication skills, it was found that the relationship between the class level and communication skills level was statistically significant and that the average score of CSES scored increased as the grade level increased from the first grade to the third grade [44].

According to the results of our study, it was found that the communication skills levels and emotional intelligence levels of the participants did not change according to the education level of the mother. Similarly, in a research conducted by Çetinkaya in 2011 on Turkish teachers, it was concluded that there was no significant difference between the emotional intelligence levels of the teachers and their mothers' educational status [45]. Unlike these results, in the study conducted by Kuzu, there was a statistically significant relationship between emotional intelligence level and mothers' and fathers' educational level [38]. Similar findings were observed in the study of Ismen in 2004 and also in the studies of Harrod and Scheer $[40,46]$.

According to the results of this research, it was seen that there was no significant difference in terms of emotional intelligence and communication skills levels according to the students' lodgings. Similar results have been obtained from other studies $[40,47,48]$. This finding supports the results of similar studies in the literature.

According to Goleman, it has been reported that attitudes such as ignoring emotions, not respecting emotions, and excessively releasing them are the most common among emotionally inadequate parental attitudes [49]. The results of the research by Ciarrochi et al. on observing the relationship between family attitudes and emotional intelligence are similar [50]. When the relevant literature is analyzed, it is seen that the contribution of parents' child-rearing attitudes to the communication skills of the child is emphasized [51-53]. However, in our study, no statistically significant difference was found between the parents' parenting attitude and communication skill score with general emotional intelligence scores and emotional intelligence sub-group scores. Similar to our study, in the study of Yeniceri et al.with medical faculty students in 2015, no significant difference was found between parents' child-rearing attitudes and emotional intelligence and emotional intelligence subscales [30].

In this study, the family type with emotional intelligence and communication skills score was examined, but no meaningful result was obtained. Similarly, in a study conducted by Karakuş et al. in 2010, emotional intelligence levels of nurses working in a training hospital were examined and no statistically significant difference was found between family type and emotional intelligence [54].

In a study by Bingöl et al. 2011, in Amasya, no statistical relationship was found between family structure, number of siblings, father and mother's education level, mother's level of work with students' communication skills assessment scale scores [55]. When the results of our study were analyzed, no statistically significant difference was found between the number of siblings and the education level of mother and father with the communication skill score, general emotional intelligence scores and emotional intelligence sub-group scores. Similarly, in a study conducted with medical students, no statistically significant difference was found between parents' education level and general emotional intelligence scores and emotional intelligence subscale scores [30]. In the study conducted by Köker et al. in 2005, it was stated that the socioeconomic level did not affect the communication skill level [56]. Similarly, in the research of Tepeköylü et al., It was found that there was no significant relationship between the student's communication skill level and the family's monthly income level [28]. In the studies of Yeniceri et al., no significant difference was found between perceived income level and emotional intelligence and sub-scales of emotional intelligence [30]. In our study, in accordance with the literature, no significant difference was found between the socio-economic status of students with the emotional intelligence and communication skills. However, unlike these results, in the research carried out by Kutlu et al. on the students of education faculty, a difference was found between the socio-economic levels in terms of emotional intelligence and communication skills scores [29]. Harrod and Scheer, in their study with young people aged 16-19, reported that as the family income increased, the emotional intelligence scores of the youth increased [40].

\section{Limitations}

Since, our study was a descriptive study, those who agreed to participate in the study may be people with high emotional intelligence and communication skills. This situation may have caused us to determine higher emotional intelligence and communication scale mean scores of the students. Also, this study only covered the students of a single university. A similar study can be done on a wider sample size, so that factors associated with emotional intelligence and communication 
skills of medical students in general in Turkey can be examined on a more comprehensive level.

\section{Conclusion}

In our study, the mean scores of the EIAS of the students in the clinic were found to be statistically significantly higher than those of the preclinical students. A weak positive correlation was found between age and emotional intelligence scale score. Those who thought that they had no difficulty in communicating between people and in expressing themselves, those who were willing to communicate, and those who thought they could listen effectively got significantly higher scores than the others from the EIAS scores. A statistically significant positive and moderate level correlation was found between the CSAS scores and the EIAS scores.

As a result, communication skills and emotional intelligence levels of medical students participating in this study differed from each other. Proper use of communication skills and emotional skills in the practice of the medical profession increases the quality of professional practice. Programs should be developed to improve students' qualifications in this direction. In a case control study conducted on medical students in the United Kingdom, communication skills of the experimental group, which were given 7 months of training to develop communication skills, showed a significant difference when compared to the control group [57]. Since, the communication skills of those with high emotional intelligence are high in our study, the trainings to be developed for developing emotional intelligence will affect their communication skills positively. From the beginning of the training to the development of the emotional intelligence, a training program that improves social relations and motivates people can be created. Educational programs may include emotional management, emotional intelligence and communication skills. In addition, guidance / counseling hours can be included to support personal development.

\section{Compliance with Ethical Standards}

Ethical Approval: Ethics committee approval and research permit were obtained from the Ethics Committee of Marmara University, School of Medicine (approval number: 09.2020.14).

Financial Support: The authors have no relevant financial information to disclose.

Conflict of Interest: The authors have no potential conflicts to declare.

Author Contributions: All authors contributed to the study conception and design. Conceptualization, formal analysis and investigation: MKA, TMS, NG, YA, , IU, MA and AT, Methodology and resources: MKA, Writing - review and editing: AT, Supervision: AT. The first draft of the manuscript was written by MKA and TMS and all authors commented on previous versions of the article. All authors read and approved the final manuscript.

\section{REFERENCES}

[1] Goleman D. Emotional intelligence. New York: Bantam, 1995:131-47.

[2] Druskat VU, Mount G, Sala F. Linking emotional intelligence and performance at work: Current research evidence with individuals and groups: New Jersey: Psychology Press, 2013.

[3] Thompson HL. Emotional intelligence, stress, and catastrophic leadership failure. In: Hughes M, Thompson HL, James Bradford Terrell JB, eds. Handbook for Developing Emotional and Social Intelligence:Best Practices,Case Studies, and Strategies. USA: Pfeiffer Inc., 2009:111-38.

[4] Mayer JD, Salovey P, Mayer-Salovey-Caruso Emotional Intelligence Test (MSCEIT). Toronto, Canada: Multi-Health Systems Inc. 2007.

[5] Parthasarathy RR. Emotional intelligence and the quality manager: Beauty and the beast? JQP 2009;31:26-48.

[6] Goleman D. Duygusal zeka. İstanbul: Varlık Yayınları, 1998.

[7] Çetinkaya Ö, Alpaslan AM. Duygusal zekânin iletişim becerileri üzerine etkisi: üniversite öğrencileri üzerinde bir araştirma. Süleyman Demirel Üniversitesi İktisadi ve İdari Bilimler Fakültesi Dergisi 2011;16:363-77.

[8] Schutte NS, Malouff JM, Bobik C, et al. Emotional intelligence and interpersonal relations. J Soc Psychol 2001;141:523-36. doi.org/10.1080/002.245.40109600569

[9] Korkut F. Okul temelli önleyici rehberlik ve psikolojik danışma [School-Based Preventive Counseling and Guidance]. Ankara: Anı Publishing, 2004.

[10] Omololu C. Communication behaviours of undergraduate medical students before and after training. Br J Clin Psychol 1984;57:97-100. doi.org/10.1111/j.2044-8341.1984.tb01587.x

[11] Korkut F. Yetişkinlere yönelik iletişim becerileri eğitimi. Hacettepe Üniversitesi Eğitim Fakültesi Dergisi 2005;28:1439.

[12] Uyer G. Hemşire-hasta iletişimi ve iletişimin hasta yönünden önemi. T Klin J Med Ethics. 2000;8:90-4.

[13] Yılmaz S, Hacıhasanoğlu R, Çiçek Z. Hemşirelerin genel ruhsal durumlarının incelenmesi. Sted 2006;15:92-7.

[14] Dilekman M, Başçı Z, Bektaş F. Eğitim fakültesi öğrencilerinin iletisim becerileri. Atatürk Üniversitesi Sosyal Bilimler Enstitüsü Dergisi 2008;12:223-31.

[15] Akyurt N, Öznaz D, Balıkçı M, ve ark. Mesleki Eğitimde İletişimin Önemi ve Marmara Üniversitesi Örneği. I Uluslararası V Ulusal Meslek Yüksekokulları Sempozyumu. Konya, Turkey: 2009:2378-92.

[16] Johnson DW. Reaching out: Interpersonal effectiveness and self-actualization. Englewood Cliffs, New Jersey: PrenticeHall, Inc, 1972.

[17] Collins S. Good communication helps to build a therapeutic relationship. Nurs Times 2009;10:11

[18] Hojat M, Gonnella JS, Mangione S, et al. Empathy in medical students as related to academic performance, clinical competence and gender. Med. Educ. 2002;36:522-7. doi. org/10.1046/j.1365-2923.2002.01234.x 
[19] Vermeire E, Hearnshaw H, Van Royen P, et al. Patient adherence to treatment: three decades of research. A comprehensive review. J Clin Pharm Ther 2001;26:331-42. doi.org/10.1046/ j.1365-2710.2001.00363.x

[20] Austin EJ, Evans P, Magnus B, et al. A preliminary study of empathy, emotional intelligence and examination performance in MBChB students. Med Educ 2007;41:684-9. doi.org/10.1111/j.1365-2923.2007.02795.x

[21] Zachariae R, Pedersen CG, Jensen AB, et al. Association of perceived physician communication style with patient satisfaction, distress, cancer-related self-efficacy, and perceived control over the disease. Br J Cancer 2003;88:65865. doi:10.1038/sj.bjc. 6600798

[22] Arora S, Ashrafian H, Davis R, et al. Emotional intelligence in medicine: a systematic review through the context of the ACGME competencies. Med Educ 2010;44:749-64. doi. org/10.1111/j.1365-2923.2010.03709.x

[23] Carr SE. Emotional intelligence in medical students: does it correlate with selection measures? Med Educ 2009;43:106977. https://doi.org/10.1111/j.1365-2923.2009.03496.x

[24] Hall L, Haggerty D, Cooper J, et al. Development and validation of a measure of emotional intelligence. Pers Individ Differ 1998;25:167-77. doi.org/10.1016/S0191-8869(98)00001-4

[25] Ergin DY, İsmen E, Özabacı N, editors. EQ of gifted youths: A comparative study. 13th Biennial World Conference, World Council for Gifted and Talented Children, Istanbul; 1999.

[26] Korkut F. İletisim becerileri degerlendirme olceginin gelistirilmesi guvenerlilik ve gecerlilik calismalari. Psikolojik Danisma ve Rehberlik Dergisi 1996;2:18-23.

[27] Durukan E, Maden S. Türkçe öğretmenlerinin iletişim becerileri üzerine bir araştırma. SBAD 2010;5:59-74.

[28] Tepeköylü Ö, Soytürk M, Çamlıyer H. Beden eğitimi ve spor yüksekokulu (besyo) öğrencilerinin iletişim becerisi algılarının bazı değişkenler açısından incelenmesi. Spormetre Beden Eğitimi ve Spor Bilimleri Dergisi 2009;7:115-24. doi. org/10.1501/Sporm_000.000.0160

[29] Kutlu M, Balci S, Yilmaz M. İletişim becerileri eğitiminin öğrencilerin kendini ayarlama ve iyimserlik düzeylerine etkisi. EJER 2007; 27: 1-4.

[30] Neşe Yeniçeri E, Yıldız E, Seydaoğulları A, et al. Muğla Sıtkı Koçman Üniversitesi Tip Fakültesi öğrencilerinde duygusal zeka ve empati ilişkisi. Turkish Journal of Family Practice/ Türkiye Aile Hekimligi Dergisi 2015;19: 99-107. doi: 10.15511/ tahd.15.02099

[31] Yousefi F. The relationship between emotional intelligence and communication skills in university students. J Iran Psychol 2006; 3: 5-13.

[32] Balcı S, Yılmaz M, Odacı H, et al. Yönetici adaylarının duygusal zekâ ve iş doyumu düzeylerinin bazı değişkenler açısından incelenmesi. VII Ulusal Psikolojik Danışma ve Rehberlik Kongresi. Malatya, 9-11 Temmuz. 2003:44-5.

[33] Acar F. Duygusal zekâ ve liderlik. Erciyes Üniversitesi Sosyal Bilimler Enstitüsü Dergisi 2002;12:53-68.

[34] Akgemci T, Aslan Ş, Özata M. Duygusal Zekanın Demografik Değişkenler Açısından Araştırılması: Hizmet sektörü
Yöneticileriyle İlgili Bir Çalışma. Ulusal Yönetim ve Organizasyon Kongre Kitab1, 2007:871-9.

[35] Pau AK, Croucher R. Emotional intelligence and perceived stress in dental undergraduates. J Dent Educ 2003;67:1023-8. doi.org/10.1002/j.0022-0337.2003.67.9.tb03685.x

[36] Weitzner MA, Lehninger F, Sullivan D, et al. Borderline personality disorder and bone marrow transplantation: ethical considerations and review. Psycho Oncology: Journal of Psychological, Social and Behavioral Dimentions of Cancer 1999;8:46-54. doi.org/10.1002/(SICI)10991611(199901/02)8:1<46::AID-PON332>3.0.CO;2-1

[37] Temur T. Dinleme metinlerinden önce ve sonra sorulan soruların üniversite öğrencilerinin dinlediğini anlama beceri düzeyine etkisi. AKEF 2010; 29:303-19.

[38] Kuzu A, Eker F. Hemşirelik öğrencilerinin duygusal zeka ve iletişim becerilerinin diğer üniversite öğrencileri ile karşılaștırmalı olarak değerlendirilmesi. Turkish Journal of Research and Development in Nursing. 2010;12:14-29.

[39] Erginsoy D. Duygusal zeka ve kişilerarası ilişkiler tarzları arasındaki ilişkinin incelenmesi (Unpublished master's thesis). Atatürk University, Institute of Social Sciences, Erzurum. 2002.

[40] Harrod NR, Scheer SD. An exploration of adolescent emotional intelligence in relation to demographic characteristics. Adolescence 2005;40:503-12.

[41] Göçet E. Üniversite öğrencilerinin duygusal zekâ düzeyleri ile stresle başa çıkma tutumları arasındaki ilişki (Unpublished master's thesis). Sakarya Üniversitesi, Sosyal Bilimler Enstitüsü Sakarya. 2006.

[42] Dicle AN. Üniversite öğrencilerinin sosyal beceri düzeylerinin duygusal zeka düzeyleri ve bazı kișisel özelliklerine göre incelenmesi: Ondokuz Mayıs Üniversitesi Sosyal Bilimler Enstitüsü Eğitim Bilimleri. Samsun. 2006.

[43] Erigüç G, Eriş H. Communication skills of students at vocational health high school: Harran University Sample. ESOSDER Summer. 2013;12:232-54.

[44] Tutuk A, Al D, Doğan S. Hemşirelik öğrencilerinin iletişim becerisi ve empati düzeylerinin belirlenmesi. CÜ Hemşirelik Yüksek Okulu Dergisi 2002;6:36-41.

[45] Çetinkaya Z. Türkçe öğretmen adaylarının iletişim becerilerine ilişkin görüşlerinin belirlenmesi. KEJ 2011;19:567-76.

[46] İsmen AE. Duygusal zeka ve aile işlevleri arasindaki ilişki. Balıkesir Üniversitesi Sosyal Bilimler Enstitüsü Dergisi 2004;7:55-75.

[47] Yılmaz M, Üstün A, Odacı H. Okul öncesi öğretmen adaylarının iletişim becerileri düzeylerinin çeşitli değişkenlere göre incelenmesi. Karadeniz Sosyal Bilimler Dergisi 2009;1:8-19.

[48] Özyazıcıoğlu N, Aydınoğlu N, Aytekin G. Sağlık yüksekokulu öğrencilerinin empatik ve problem çözme becerilerinin incelenmesi. Anadolu Hemşirelik ve Sağlık Bilimleri Dergisi 2009;12:46-53.

[49] Goleman D. The socially intelligent. Educational leadership. 2006;64:76-81.

[50] Ciarrochi J, Chan AY, Bajgar J. Measuring emotional intelligence in adolescents. Pers Individ. Differ 2001;31:110519. doi.org/10.1016/S0191-8869(00)00207-5 
[51] Yavuzer H. Gençleri anlamak: Ana-babaların en çok sorduğu sorular ve cevaplariyla. 2. baskı. İstanbul: Remzi Kitapevi, 2005:40.

[52] Yavuzer H. Çocuk psikolojisi. 27. Baskı. İstanbul: Altın Kitaplar Yayınevi, 2005;33.

[53] Demiriz S, Öğretir AD. Alt ve üst sosyo-ekonomik düzeydeki 10 yaş çocuklarının anne tutumlarının incelenmesi. KEJ 2007;15:105-22.

[54] Karakuş Ç. Çalışma hayatında iş tatmini ve iş stresi: özel bir hastanede çalışan hemşireler üzerine bir araştırma. AEUIİBFD 2019;3:92-104.
[55] Bingöl G, Demir A. Amasya sağllk yüksekokulu öğrencilerinin iletişim becerileri. MEDJ 2011;26:152-9. doi:10.5222/J. GOZTEPETRH.2011.152

[56] Köker S, Evrengöl A, Canat S. Ergenlerin ana babaları ile iletişimlerini algılama düzeyleri. Çocuk ve Ergen Ruh Sağlığı Dergisi 2005;1:75-8.

[57] Fletcher I, Leadbetter P, Curran A, et al. A pilot study assessing emotional intelligence training and communication skills with 3rd year medical students. Patient Educ Couns 2009;76:376-9. doi.org/10.1016/j.pec.2009.07.019 